\title{
When the Ordinary Meets the Jiggery-Pokery: Towards a Wittgensteinian Reading of Lindgren's Karlson on the Roof
}

\author{
Tomasz Zarębski ${ }^{1}$ [
}

Published online: 26 March 2020

(c) The Author(s) 2020

\begin{abstract}
The article is mainly concerned with philosophical interpretations of Astrid Lindgren's Karlson books. Inspired by Gaare and Sjaastad's reading of Pippi Longstocking, the article discusses the philosophical ideas embedded in Lindgren's books about Pippi Longstocking, stressing, in particular, Lindgren's implicit critique of Western culture. Next, an attempt is made unsuccessfully to locate the figure of Karlson of the Karlson trilogy (Karlson on the Roof, Karlson Flies Again and The World's Best Karlson) in this critical context. Instead, it is shown that the figure of Karlson may be better understood in the context of the later Wittgenstein's conception of language games. In such a reading, Karlson appears as a figure of the other. The otherness can be here understood as a distancing act from everyday language games, and the habits and Lebensformen that they function in. While the existing language games' rules constitute the sphere of the ordinary, the deviation from them forms the sphere of unusualness, extra-ordinariness, otherness, or "jiggery-pokery," to use Karlson's words. Presenting such otherness to the reader implicitly serves two pedagogical goals. First, it acquaints children with possible forms of "being other." Second, it opens a sphere of "whatifness", that is, the account of what the world would look like if certain concepts, or practices, were different. It is claimed that the domain of "whatifness", by presenting alternatives to the ordinary, brings the reader closer to a better understanding of the conditions of their own Lebensform.
\end{abstract}

Keywords Children's literature · Astrid Lindgren · Karlson on the Roof · Pippi Longstocking $\cdot$ Wittgenstein $\cdot$ Language games $\cdot$ Otherness $\cdot$ Nonsense

\footnotetext{
Tomasz Zarębski is an Associate Professor at the University of Lower Silesia, Department of Education (Wrocław, Poland). He earned both his PhD and habilitation degree in philosophy. He deals mainly with the philosophy of language (Brandom, Wittgenstein), theory of argumentation and rationality (Toulmin) and epistemology. He is also interested in the application of philosophical ideas in critical readings of children's literature.
}

Tomasz Zarębski

tomasz.zarebski@dsw.edu.pl

1 Department of Education, University of Lower Silesia, Wrocław, Poland 


\section{Introduction}

The literary production of Astrid Lindgren has given rise to many interpretations (Kümmerling-Meibauer and Surmatz, 2011), not only within literary critique (Coats, 2007; Dymel-Trzebiatowska, 2013; Nikolajeva, 2011, 2007; Scott, 2007), but also within educational (Lundqvist, 1979, 1989; Zweigbergk, 1965; see also Strömstedt, 2015, pp. 209-219) and psychological studies, not least in bibliotherapy (Dymel-Trzebiatowska, 2014). A particular strand in Lindgren criticism is one that attempts to set it in a specific philosophical context. A review and exploration of such ideas is presented, for example, in the book Pippi og Sokrates. Filosofiske vandringer $i$ Astrid Lindgrens verden by Norwegian authors Gaare and Sjaastad (2002). The authors are principally focused, unsurprisingly, on the figure of Pippi Longstocking, undisputedly the most popular character of Lindgren's books, but also refer to others, such as Karlson, Emil, Ronia or Lotta. The aim of this article, however, is to offer a philosophical reading of Lindgren's Karlson trilogy: Karlson on the Roof, Karlson Flies Again and The World's Best Karlson. Inspired by Gaare and Sjaastad and their discussion of Pippi and philosophy, I shall turn my attention to the figure of Karlson, and approach him from a Wittgensteinian perspective, looking at how his language games constitute the representation of otherness.

My construal of Karlson's otherness corresponds broadly to the concept of literary nonsense as developed, for example by Tigges (1988), Chukovskiǔ (1963) or Anderson and Apseloff (1989), where features such as, topsyturvydom and meaning subversion count as typical features of word-play nonsense (see Tullloch 2015 , p. 8). In this view, nonsense is seen not as something that makes "no sense", but rather as something that reveals "more than no sense" (Tulloch, 2015, p. 38) and implies a disruption of linguistic and cultural norms (Nodelman and Reimer, 2003, p. 97). It is assumed that nonsense has the potential to free a child from "the tyranny of the norm" (Nodelman and Reimer, 2003, p. 95) that is associated with adult normalcy and adults' projection of this normalcy on childhood. The counterpart of nonsense so understood, in my reading of Karlson, is the concept of jiggery-pokery.

Lindgren published the first book on Karlson, Karlson on the Roof (Swedish original: Lillebror och Karlsson på taket) in 1955, the second Karlson Flies Again (in Swedish: Karlsson på taket flyger igen) in 1962, and the third The World's Best Karlson (Karlsson på taket smyger igen) in 1968-a number of years after the Pippi books $(1945,1946,1948)$, which were her first successful works. The Karlson trilogy has never gained such worldwide fame as the Pippi trilogy has, and judging from the numbers of translations, as presented about the Astrid Lindgren Company webpage (2020), Karlson is also less popular than several other books: Brothers Lionheart, Emil of Lönneberga, the Bullerby books and Ronia the Robber's Daughter. The exception are the countries of Central and Eastern Europe, particularly in the former Soviet Union, where-as Nikolajeva reminds us- "it was the first book translated into Russian and remained the only book for many years" (2007, p. 3); the books were turned into theatre plays, and the figure 
of Karlson appeared in numerous merchandise items. Nevertheless, Karlson does not feature prominently in books concerning Lindgren's life and production (e.g. Edström, 1996, 2000; Strömstedt, 2015).

The book is a story about a seven year old, well-mannered boy, Smidge, living in Stockholm, and feeling rather lonely because of his being the youngest sibling - his brother and sister are much older. He dreams about having a little puppy to play with. One day, sitting in his room, a figure with a propeller on his back flies through the window and soon becomes his playmate. He introduces himself as Karlson on the Roof. He lives, as can be expected, on the roof behind a chimney, and is able to fly with the help of his propeller. However, Karlson, although admired by the boy, is often rude, sulky, opinionated and greedy, always ready for mischief. At the same time, he is full of risky ideas (like taking Smidge to fly with him on his back) and likes jiggery-pokery, often leading Smidge into trouble. Karlson is not a boy, but "a man in his prime," as he keeps saying. He is short and chubby, but, in his own opinion, the most handsome person in the world, and he is uncritically convinced he is the best at literally everything. He is undoubtedly a bad model to follow for children. Yet, his humour, unconventionality, and language-play also make him appealing and charming.

\section{Karlson and Philosophy}

Pippi Longstocking is a character to which a number of philosophical ideas may be ascribed. According to Gaare and Sjaastad, she is, first and foremost, found to be a contemporary counterpart of Socrates-in her inquisitiveness in asking perplexing questions and pursuing unexpected and unobvious answers as well as in her cheerful and humorous approach to every problem and truly Socratic irony (2002, pp. 89-111).

In opposition to Pippi, Karlson does not easily identify with any particular philosophical stance. In many respects, he is very different from Pippi. He is no Socrates: his questions and remarks are bothersome, unconstructive; and he is malicious rather than ironic in the Socratic sense. Neither does he appear as Nietzschean's Übermensch (2004). Thus Gaare and Sjaastad's claim that "Emil and Karlson on the Roof are high-class Nietzschean transvaluators of all ancient values" (2002, p. 127) cannot really be defended. At most, Karlson destroys some existing values, but he does not create new ones. He has a strong character, being also perceptive and inventive, but his "transvaluating" potential is mostly overcome by his egotistical impulses. It seems that only one of Nietzsche's ideas applies to Karlson to a greater extent, namely perspectivism.

In contrast to Pippi, it is difficult to see Karlson as a critic of culture. It is true that he typically undermines the existing rules of behaviour, the set meanings in communication, the fixed ways of performing social or family rituals (e.g. greeting a newly-arrived uncle at the door with respect), even the significance of sheer misbehaviour or misdeeds (such as theft, borrowing without giving back, cheating in games, breaking promises etc.). Yet, for all that, this does not add up to a critique of Western culture. It rather consists, one would say, in distorting things and showing 
not only different, "unknown" facets, but sometimes hardly tolerable aspects of them. Karlson, willy-nilly, aims at showing some other world, some other possibility of seeing things in the sense there is also a sort of "clash of cultures" between him and the Stevenson family, which, however, does not incite the reader to change or improve the world.

The difference between Pippi and Karlson is striking. While Pippi is admirable in many ways, Karlson is not. As Astrid Lindgren herself once stated: "It would somehow go that way. Karlson did not at all want to be nice" (after Strömstedt, 2015, p. 260). While Pippi is generous and charitable, Karlson is evidently a miser: he scrimps and saves almost every five-öre coin that he happens to possess. Karlson is conceited and opinionated, contra Pippi, who, for all her self-confidence, reveals more common-sense and honesty and sense of equity. As a result, "in the book he appeared as an obnoxious, touchy, sulky, unbearable guy, in whom all our unpleasant and silly, grudgingly disclosed features were emphasised and multiplied" (2015, p. 260).

Gaare and Sjaastad rightly pay special attention to Karlson's playfulness, but first of all, his tampering with language. They discern a strong affinity between him and Humpty Dumpty in Carroll's Through the Looking-Glass, and What Alice Found There-who always seems to be invincible in arguments due to the fact that he deliberately changes the meanings of the words used in discussion. For Gaare and Sjaastad, it is evident—-both in Karlson's ability to invent new words (such as "tirritate"), freely fiddling with their meaning (e.g. his catchphrase "That's a mere trifle") so that they serve his own interests - that he predominantly manipulates Smidge (2002, p. 193). It is he who-like Humpty-Dumpty-is the master of discourse.

\section{Wittgenstein, Language Games and Otherness}

Ludwig Wittgenstein (1889-1951), an Austrian philosopher working and teaching in Cambridge, Great Britain, advanced, in his later philosophical thought, a conception of language games, which may be of use in interpreting Lindgren's books about Karlson, thus providing an alternative to Gaare and Sjaastad's understanding of this figure. The concept has been presented in a set of remarks and considerations collected in Philosophical Investigations (1986). In order to sketch it for the purpose of this article, it is essential to underscore that, in the thinking of the later Wittgenstein, the meaning of our linguistic expressions is not only dependent on the referential relation with the objects of the external world. Instead meanings hinge, rather, on our actual uses of these expressions, together with the whole social and "environmental" context that they are used in, or, in Wittgenstein's words: "I shall also call the whole, consisting of language and the actions into which it is woven, the "language-game"' (1986, §7).

Language as a game is a rule-governed activity. Hence language games have their grammars - not only in the traditional sense, but also grammars of wider practical usage. If an expression is to make sense, be intelligible, it has to follow the accepted grammar of the game. Accordingly, our learning the meaning of something also consists in our practical knowledge of how to use a linguistic expression, its 
appropriate use, and our understanding of the appropriate context. Moreover, our every utterance may be treated as a move in a game, and is a part of a more or less complex system of rules: as with games, certain rules are intelligible and thus belong to these games, while some others are foreclosed. In a similar manner, certain linguistic moves belong to a set of acceptable rules, whereas some others are beyond it (Glock, 1996, pp. 193-94).

What is crucial for Wittgenstein is that language games are deeply rooted in human praxis (Dehnel 2016, pp. 275-328) and have to comply with neither formal calculi nor such semantic relations (and inferences) that are in principle possible, but not practised. Therefore the games are what we actually live by. One can say that they are ordinary and taken as obvious, "which no one has doubted, but which have escaped remark only because they are always before our eyes" (Wittgenstein, 1986, §415). They are part of "the natural history of human beings" (1986, §415). At the same time, the set of rules governing our linguistic and social behaviour is not always definite and strictly limited (Cavell, 2000), but may possibly be developed "as we go along" (Wittgenstein, 1986, §83). Nevertheless, they are all interwoven into our "form of life" (1986, §19).

The accepted language games can comprise both different linguistic items (i.e. concepts) and practices that they dovetail with: promising, greeting, asking and answering a particular way, celebrating birthdays, cooking etc. Yet, in the last resort, they can also serve as categories for analysing wider social institutions and political relations (Winch, 1958). A significant part of Wittgenstein's later thought is his creation of fictitious games, and his reflections on these games (see Glock, 1996, pp. 194-95). By analysing these language games, which are often simple and primitive, he first considers the resulting Lebensform, or mode of life. Secondly, he attempts to understand our own language and form of life in the here and now.

Against the background of later Wittgenstein, a specific concept of otherness can be set out. Namely, assuming that what constitutes our everyday language games and forms of life can be labelled as the ordinary, or the usual, then what deviates from it can be termed the extra-ordinary, or the unusual. That being so, what constitutes the domain of the unusual, can be called the otherness. This otherness, in the most general sense, relies on misusing the rules of the accepted, ordinary language games-either breaking them deliberately or through a lack of understanding. Thus one can conclude that knowing otherness, or our opening up to it, might be achieved by imagining and analysing different forms of life and diverse language games. In the last resort, through such analyses of otherness, we also acquire better self-understanding of our human condition.

\section{Smidge and Karlson: The Ordinary and the Jiggery-Pokery}

The later Wittgensteinian account of otherness as a practise, particularly as a linguistic one, that diverges from the extant practices, or Lebensformen, may be of great use in reading Karlson on the Roof. For it seems that the underlying idea of the whole book is the tension between the existing, ordinary language games, as being embedded in relevant accepted social practices, particularly in Smidge's family, and 
the unusual, extra-ordinary language games which are revealed through Karlson's "jiggery-pokery." The latter constitutes a sphere of linguistic and social "whatifness" that comes into effect by Karlson's breaking the ordinary, extant rules of both speech and conduct. As a matter of fact, the ordinary and the jiggery-pokery-the latter construed as unusualness or extra-ordinariness - can be thought of as key interpretative concepts for the reading of the Karlson books. What is the role of the jiggery-pokery in its entering into the ordinary? Apart from its being an inexhaustible source of humour, it seems that it tacitly serves two aims: firstly, it helps the reader open to otherness, to see how it might be to deal, or live, with someone who either plays by different rules, or who pointedly breaks the rules of ordinary language games; secondly, it acquaints the reader with unusual, hidden aspects of ordinary things, as well as with strange, unexpected aspects of the meanings of linguistic expressions and activities. That being so, it can lead readers to a better understanding of life and of the language games we engage in. By stepping into the sphere of "what if", excelling in our own practices and exploring otherness, we are free to attain a critical self-understanding of ourselves.

The category of ordinariness appears explicitly in Karlson on the Roof as early as in the opening pages, where it is juxtaposed with the unusualness of Karlson:

In a perfectly ordinary street in a perfectly ordinary house in Stockholm lives a perfectly ordinary family called Stevenson. It consists of a perfectly ordinary father and a perfectly ordinary mother and three perfectly ordinary children, Seb, Sally and Smidge. [...] Smidge most definitely is ordinary, there's no question about it. (Lindgren, 2008, pp. 1-2)

And so completely ordinary are also Seb and Sally. The one who is not ordinary-i.e. who is extra-ordinary, strange-is Karlson. Why is he not so ordinary as the Stevensons and other Stockholmians? First of all, he "lives in a special little house up on the roof", and second, he can fly-not in a plane, but by himself, with a special propeller installed on his back. Accordingly, Karlson does not live far away. His home-world on the roof (a small house behind a big chimney) is quite close to Smidge's, the Stevensons' flat being located on the highest floor. Yet "most people don't notice houses as small as Karlson's, even if they trip over them." He was once seen by a chimney sweep, who said to himself "That's strange", but soon got back to his ordinary job and "never thought of it again". Ordinary people "don't know you can live on roofs" (2008, pp. 2-3), which means that they usually do not cross beyond the ordinary routines of their Lebensform, in a lifetime, not even in their thoughts.

The otherness of Karlson is mostly hidden from the ordinary world, being only gradually revealed to other people. First, he openly enters the life of Smidge, the youngest child in the family and the one who is lonelier than his far older siblings. Karlson visits him flying in through the window; on another day, Smidge also visits Karlson in his house on the roof, as the first ordinary person to do so. Smidge plays and interacts with Karlson, but when he enthusiastically tells his parents about it, they do not believe him. They keep on saying that Karlson "doesn't exist" (2008, p. 16) and that "he's an invention" (2008, p. 52). Later on, he puts in an appearance before Smidge's schoolmates Jemima and Kris when they play in Smidge's room 
(2008, 109-110). Next, he appears before other children from Smidge's neighbourhood, when organising a magic show with a small dog which Smidge has found in the street (2008, p. 133 et passim). Only at the very end of the first book, during Smidge's 8th birthday party, does he make a personal appearance before the whole family - to their utter surprise and dismay. While Smidge's mother only manages to gasp "I think I'm going to faint", his father admonishes them: "Don't tell anybody about this, not anybody-Nobody would believe you-But if they believe, we wouldn't get a minute's peace for the rest of our lives" (2008, p. 162). The secret is kept up in the family in the second Karlson book, Karlson Flies Again. The only other person who gets to know him is a temporary housekeeper, Miss Crawley (2010, pp. 129-130), nicknamed Creepy Crawley by Smidge. Finally, in the third book The World's Best Karlson, he is noticed by some from the Vasa district and reported to the police on suspicion of being a flying spy. As a result, in the last chapter, he appears in a Stockholm newspaper — cleared of the charge of espionage - and hence introduced to a wider audience (2009, pp. 200-203). It all can be thought of as a way of inserting otherness into the ordinary: beginning from the child Smidge, through other children, family, housekeeper, and ending with the newspaper article.

\section{The Otherness of Karlson}

In what way is Karlson unusual or extra-ordinary? To begin with, it is impossible to say whether he is a child or an adult man. He "seemed rather childish for a grownup man" (2008, p. 8), and looks as if he were "an unusually tubby little schoolboy", though "The boy didn't seem quite normal, it must be said" (2009, pp. 200-201). It is impossible to tell his age and he himself does not know it, always claiming to be a man in his prime. Furthermore, while Smidge has both his name and surname, Steven Stevenson, Karlson has only one: "Plain Karlson and nothing else" (2008, p. 8). Instead of greeting others in an ordinary way, he says "Heysan hopsan". He is very proud of himself, even conceited, saying "I'm a handsome, thoroughly clever, perfectly plump man in my prime” (2008, p. 9), sometimes singing: “...how ever so clever I am... And more or less perfectly plump .... yum” (2008, p. 27). Moreover, he maintains that he is the world's best at everything. Thus, in the first Karlson book, he ostensibly is the best stunt flyer, a steam engine driver, motor mechanic, cockerel painter, speedy cleaner, putter-together of building sets, jiggery-poker, nanny, fire putter-outer, ghost, dog handler, magic maker, cake eater, grandson. In the same vein, he overuses the word thousand, too often saying that he has got thousands of something: of steam engines at home, of nice pictures, of flying dogs on the roof etc.; while actually having in mind several, one (e.g. a cockerel painting) or none (e.g. a steam engine). His sayings are also characteristic of him, such as: "Easy now, take it easy" (e.g. 2008, p. 9) and "That's a mere trifle" (e.g. 2008, p. 11), uttered in cases of the highest danger (e.g. the explosion of a steam engine and the flames of fire on a book-case during their play) or some considerable loss (like scorch marks on furniture or Smidge's flooded flat). However, if the loss is his own, he no longer claims it to be a mere trifle (2008, pp. 38-39). 
Despite his evident flaws, such as sulking, greed (especially for sweets), overbearingness and megalomania, Karlson is the best playmate for Smidge. "Whenever Karlson flew in, things turned exciting and there were adventures to be had" (2008, p. 4). He needs fun every spare moment and is always fond of jiggery-pokery. It turns out that Karlson is not only a mischievous master of discourse (Gaare and Saastad). As a matter of fact, in many situations, he displays a strong, clear sense of fairness and equity. He saves Oskar, "a poor chap" from the country, who has come to Stockholm, from being robbed by two thugs Spike and Rollo (2008, pp. 86-93). He cheers up a hungry baby-Sweetie-Pie, whose parents have gone out gallivanting - by feeding it a bottle of milk that he has pinched from a balcony nearby (2008, pp. 78-86). And, disguised as a ghost, he chases away the burglars (again Spike and Rollo) when they search Smidge's flat for money and valuables (2008, pp. 115-119). Obviously, he lacks courtesy and good manners. However, it seems that what is regarded as his rudeness, selfishness and lack of good-manners belongs to Karlson's sphere of jiggery-pokery.

What then is jiggery-pokery? As an interpretative category of the book, it covers the whole domain of unusualness or extra-ordinariness. In this sense, it is the opposite of ordinary. On the one hand, it means playing pranks or practical jokes on someone, which sometimes takes the form of irritating, "figurating" or even "tirritating" someone-meaning the same as "irritating" but "more fiendish" (2010, p. 52), such as stealing buns from Miss Crawley. ${ }^{1}$ In this sense, it is something unusual as referred to the ordinary routines in Smidge's family and in normal, everyday life, for example in Stockholm. On the other hand, it is also, at the same time, every activity that deviates from the ordinary language game actually played, that breaks the rules of this game: both on a purely linguistic level and on a social, interactional level of our practices, or forms of life. For Smidge and then for his family, Karlson is a figure that opens the domain of "whatifness". It is what your mode of life would be like if some of your habits, or practices, were somehow different, and if some of the words you use meant something different. Karlson epitomises such alternatives and puts them into effect through his jiggery-pokery. It remains unclear, however, whether jiggery-pokery is Karlson's actual, "private" mode of life on the roof, or is only a way of showing other aspects of meanings, by putting them in the context of other language games. It seems plausible that he represents otherness in the later Wittgensteinian sense, as playing language games-by rules differing from the norm.

\footnotetext{
${ }^{1}$ Later on, especially in the third book on Karlson, he keeps saying that there are three ways of treatment you give to some people: "Tirritation, jiggery-pokery and figuration" (e.g. Lindgren, 2009, p. 57), thus not being strictly logical, because the three categories seem to overlap. Nevertheless, the extension of the concept of jiggery-pokery is definitely the most comprehensive.
} 


\section{Karlson as a Language Games' Rules Misuser}

Karlson's jiggery-pokery may be classified into six categories. First we have semantic rule-breaking such as, "I am only going to scare the life out of them a little bit" (2008, p. 113), when he gears himself up for chasing away the burglars, Spike and Rollo. It is of course semantically contradictory to scare the life from someone a little bit. Another example is when Karlson calls his granny "the naggiest nagger" (2010, pp. 12-13) with apparent positive overtones, whereas the accepted meaning of the term is negative. In a similar vein, Karlson's understanding of "sleep problems" is evidently at odds with the accepted meaning of the term: "I sleep like a log at nights, and in the mornings, but it's the afternoons that are the worst, I just lie there tossing and turning" (2010, p. 103).

The second category concerns not only semantic rule-breaking, but also pragmatic rules of communication in the Gricean sense. ${ }^{2}$ According to Grice, people communicate according to the cooperative maxims of communication, aiming at their speech being informative, truthful, relevant and perspicuous (1991, pp. 24-31). Contrary to these maxims, Karlson is, quite often, hardly informative, relevant, clear and truthful. The case of his making an appointment with Smidge is a good example of such over-literal misuses. "I'll be there about three or four or five o'clock, but not a minute before six [...]. No later than seven anyway" [...]. "But hardly before eight. And make sure you're ready at nine o'clock or roughly thereabouts, because that's when it all happens" [...] "Roughly [...] I said I'd be coming roughly, and so I have" (Lindgren, 2008, p. 54). As an actual fact, Karlson appears and vanishes whenever he wants: "He'll only ever say when he's coming roughly, and that can mean any time" (2008, p. 126). The same could be said about his use of the word "thousands", one of Karlson's, favourite expressions, as well as his habit of saying that he is the best at everything, not to mention his responding that he is a man in his prime, when asked about his age.

The third class constitutes pragmatic rules concerning social behaviour (in both the traditional and Wittgensteinian sense), or proprieties of rudimental courtesy. Such rules are notoriously broken by Karlson. Much as he likes Smidge, he addresses him offensively, calling him an "old sack of hay" (2008, p. 7), "a silly sausage” (2008, p. 50), "a greedy little boy” (2008, p. 68), "you little pig” (2010, p. 18), and, (in front of his family): "you can't expect much of some people" (2010, p. 10). Sometimes, when coming to Smidge, he does not bother to say anything but "Heysan hopsan" save for asking: "Is there anything to eat? Any meatballs or [...] a bit of cream cake?" (2010, p. 9). When about to be introduced to Smidge's family, he does not use polite phrases such as, "It would be a pleasure to meet your parents", "It will be really nice to know them", but instead, "It'll be nice for them to meet me, handsome and altogether clever as I am!” (2008, p. 20). When Smidge agrees to do him a favour and fetch him meatballs from the kitchen before dinner, he does not care to

\footnotetext{
${ }^{2}$ I take Gricean account to be an exemplification of Wittgenstein's more general concept of language games, i.e. as a clarification of the way in which we actually communicate, the basic game that is actually played by us.
} 
express his gratitude, but instead rushes him in unpleasant manner: "But hurry up. You don't get full up just looking at pictures [...]!" (2008, p. 23).

The fourth category concerns Karlson's drawing illegitimate inferences from the uses of accepted concepts. For example, when he sees a telephone number written on the collar of Ahlberg, the dog that Smidge found, Karlson concludes that "The dog's got his own telephone" (2008, p. 131) at home and can use it. Another time he tells a made-up story about his dog who has called an old major's wife and on her remark that "That's a wrong number" replied "Why did you answer, then?" (2008, p. 131), which semantically fits the concept of the number's wrongness, but is utterly incorrect. Similarly, on a magic show held "for good causes", he does not imply charity, but himself: "there's only one really good cause, and that's Karlson on the Roof" (2008, p. 132), which means that all toffees collected as ticket payments go directly to him. In other situations, he explains that "a flying dog" might mean that Karlson is flying with a dog, rather than the dog flying on its own (2008, p. 138). Another example is when a drawing of a rabbit might as well mean a drawing of a fox with a rabbit inside a fox's stomach (2010, p. 97). On Smidge's 8th birthday, seeing a cake with eight candles, Karlson quite logically suggests: "Can't you ask your mum to let you have eight cakes and one candle instead?" (2008, p. 144). A final example is when Karlson says that his granny's nagging words, "change your socks" means that he should "put the left sock on my right foot and the right sock on my left foot" (2010, pp. 13-14).

The fifth category refers to Karlson's understanding of mathematical operations, mainly addition and simple divisions. Here, Karlson does not understand mathematics as a formal, a priori field, abstracted from empirical experience and everyday life. Instead, he takes it to happen in real life and on concrete objects in particular situations:

"Say you get three apples from Mum and two from Dad and two from Seb and three from Sally and one from me..." [...]

"I knew you were the meanest [...]"

"Yes, how many apples will you have then?" [...] "You'll have eleven apples" [...]

"But you're wide of the mark there, because I pinched twenty-six apples from a garden at Lidingö the night before last, and I've still got three left, plus one I've only taken a few bites of" [...]

"Hah, I know you're lying (...) because there are no apples on trees in June" [...]

"Well, where did you (...) get yours from, then?" (Lindgren, The World's Best Karlson 86-89)

On another occasion, he persuades Smidge that it is better to have five 5 öre coins than one of 25 öre (2008, p. 57). In a similar manner, he divides things, usually by two. When having ten buns on a plate, he urges Smidge on to share it so as they eat seven buns each. Then he "gobbled" his seven and says: "They teach you children such a daft 
way of counting at school these days. But I shouldn't have to suffer for it. We'll take seven each, like I said, and these are mine" (2010, p. 62). Another time, he insists on dividing a peach so that Smidge gets the stone and Karlson the edible part (2009, p. 20 ), or to share a bag of toffees in the way that the former gets a bag and the latter toffees (2009, p. 19).

The sixth class, the most comprehensive, comprises social rules, institutions and rituals. Here, such social practices as using money, buying and selling, borrowing, finding something to appropriate it etc. come to the fore. Similarly, the manners of promising and keeping promises, politely welcoming someone, playing games, helping someone in their work, having one's birthday, making a bet, caring for someone ill, etc. are definitely understood by Karlson in a way that markedly diverges from the norm. Karlson usually takes things, especially food, without asking and getting permission for it (e.g. 2010 , p. 66). He never ponders over the value of things taken, always paying 5 öre, no matter whether he takes, for example, one bun or a plate of them. He pays the same sum for every damage that he has done. He also thinks that selling his big toes to Smidge while still having and using them would be a quite good deal for Smidge. Sometimes he borrows something, e.g. a bottle of milk for Sweetie-Pie (2008, pp. 82-83) from a nearby balcony, without any intention of taking it back. At the same time he claims it is still borrowing, not stealing on his part. Similarly, when he takes a taxi driver's wallet full of 5 öre coins, he calls it "finding" rather than "stealing" although he saw the driver drop it (2010, p. 67).

When it comes to promises, Karlson employs a stratagem in his interpretation of Smidge's promise to Sally "not [to] show myself in the sitting room all evening" (2008, p. 41). Karlson persuades Smidge to play in a tent, in the sitting room, with a torch under a blanket, so that Sally will not see him directly. Another example is when Karlson "honours" a guest with a pistol salute, even if it is so sudden, unexpected and loud that the comer, uncle Julius, collapses in a faint (2009, p. 73). When playing a game such as hide-and-seek or beggar-my-neighbour, he either does not understand the rules or cheats to win (2008, p. 105, 2009, p. 128). His helping Smidge in cleaning Karlson's house might as well mean Karlson's lying on the bed and singing so as Smidge has a pleasant work atmosphere (2010, pp. 33-34). On another occasion, he claims that birthdays can be celebrated more often than once a year, simply when you fancy a party or receiving gifts (2009, pp. 38-39). When making a bet with Smidge, he misuses the mere idea of betting, winning or losing it, as if he did not understand or accept any bet if he does not get what he wants (2008, p. 65 et passim). When he claims to be ill, he deliberately takes the external manifestations of looking after someone who is illsuch as consoling, worrying about the temperature, giving small gifts, wearing a scarf that itches etc.- - for the actual state of one's being ill; yet afterwards, admits it having been jiggery-pokery and imagination on his part (2008, p. 102).

\section{Conclusion}

Karlson on the Roof is one of the most problematic figures in Astrid Lindgren's oeuvre. I have argued that he may be better understood in the context of the later Wittgenstein's thoughts on language games. In such a context, the other can be seen 
as a misuser of the rules of language. According to such a view, as applied to Karlson books, he is the protagonist who steadily misuses the accepted rules: either by deliberately breaking them or possibly displacing concepts taken from language games. The accepted, extant Lebensform, with its language games rules, constitutes the sphere of the ordinary, whereas Karlson's different activities, i.e. his misuses of the rules, represent the sphere of the jiggery-pokery, as he himself keeps calling it in the book, a term which can stand for the unusual, the extra-ordinary or otherness. Thus, in Smidge's interactions with Karlson, the ordinary meets the jiggery-pokery.

Karlson's misuses of the rules, his jiggery-pokery, may be considered a parallel to the nonsense as Tulloch (2015), Tigges (1988), Chukovskiǔ (1963) or Anderson and Apseloff (1989) understand it. In accordance with their views, it may be said that nonsense might have several functions. It might help the reader realise that what is called "normal" is, in fact, a social construct and as such may be undermined and reshaped; one can defy "the tyranny of the norm" (Nodelman and Reimer, 2003, p. 95). It might further engender philosophical and educationally formative questions about the nature of language, the criteria of proper or improper actions, and the diversity of life and human postures (Tulloch, 2015, p. 2). Finally, "the fact that children can recognize the way nonsense subverts common sense can be regarded as evidence that they have mastered certain concepts (...), nonsense may confirm children's knowledge and their attempts to make sense of the world around them (Tulloch, 2015, pp. 38-39).

Against this background, two pedagogical functions of Karlson's jiggery-pokery can be distinguished. The first is that the meeting of the two spheres opens the reader to otherness, offering different possible forms of being other. It has to be emphasised that the reason why Karlson breaks the rules is not essential. Whether the jiggerypokery is done on principle, or is an instrument for his selfish, self-seeking goals is not decisive. In reality, it does not actually matter if the motivations are egoistic (which is closer to Karlson's case) or incomprehensibly altruistic. The point is that his behaviour deviates from what can be called the ordinary. The second function is that Karlson's jiggery-pokery opens the sphere of "whatifness", i.e. the account of what the world would look like should certain concepts, or practices, be altogether different. In turn, this makes it possible for the reader to approach a better understanding of their own Lebensform.

\section{Funding Funding was provided by University of Lower Silesia (PL) (Grant No. 251TZ-DPFPP20).}

Open Access This article is licensed under a Creative Commons Attribution 4.0 International License, which permits use, sharing, adaptation, distribution and reproduction in any medium or format, as long as you give appropriate credit to the original author(s) and the source, provide a link to the Creative Commons licence, and indicate if changes were made. The images or other third party material in this article are included in the article's Creative Commons licence, unless indicated otherwise in a credit line to the material. If material is not included in the article's Creative Commons licence and your intended use is not permitted by statutory regulation or exceeds the permitted use, you will need to obtain permission directly from the copyright holder. To view a copy of this licence, visit http://creativecommons.org/licen ses/by/4.0/. 


\section{References}

Anderson, Celia C., and Apseloff, Marilyn F. (1989). Nonsense Literature for Children: Aesop to Seuss. Hamden, CT: Shoe String Press.

Astrid Lindgren Company. (2020). Astrid Worldwide. Accessed February 10, 2020 from https://www. astridlindgren.com/en/astrid-worldwide.

Carroll, Lewis. (n.d.). Through the Looking-Glass, and What Alice Found There. Accessed December 18, 2019 from https://www.gutenberg.org/files/12/12-h/12-h.htm\#link2HCH0006.

Cavell, Stanley. (2000). Excursus on Wittgenstein's Vision of Language. In Alice Crary and Rupert Read (Eds.), The New Wittgenstein (pp. 21-37). London and New York: Routledge.

Chukovskiŭ, Korneŭ. (1963). From Two to Five. Trans. and ed. Miriam Morton. Los Angeles: University of California Press.

Coats, Karen. (2007). Pippi Longstocking and the Father of Enjoyment. Barnboken, 20(1-2), 15-23.

Dehnel, Piotr. (2016). Myśli a sposoby życia. Kraków: Universitas.

Dymel-Trzebiatowska, Hanna. (2013). Translatoryka literatury dziecięcej: analiza przekładu utworów Astrid Lindgren na język polski. Gdańsk: Wydawnictwo Uniwersytetu Gdańskiego.

Dymel-Trzebiatowska, Hanna. (2014). W poszukiwaniu odrobiny pocieszenia. Biblioterapeutyczny potencjat utworów Astrid Lindgren z perspektywy narratologii i psychoanalizy literackiej. Gdańsk: Wydawnictwo Uniwersytetu Gdańskiego.

Edström, Vivi B. (1996). Astrid Lindgren oczami Vivi Edström. Trans. Halina Thylwe. Lund: Svenska Institutet.

Edström, Vivi B.. (2000). Astrid Lindgren. A Critical Study. Trans. Eivor Cormack. Stockholm \& New York: R\&S Books.

Gaare, Jørgen, and Sjaastad Øystein. (2002). Pippi i Sokrates. Trans. Iwona Zimnicka. Warszawa: Jacek Santorski \& Co Wydawnictwo.

Glock, Hans-Johann (Ed.). (1996). A Witttgensteim Dictionary. Oxford: Wiley-Blackwell.

Grice, Paul. (1991). Studies in the Way of Words. Cambridge, MA: Harvard University Press.

Kümmerling-Meibauer, Bettina, and Surmatz, Astrid (Eds.). (2011). Beyond Pippi Longstocking: Intermedial and International Aspects of Astrid Lindgren's Works. London: Routledge.

Lindgren, Astrid. (2008). Karlson on the Roof. Trans. Sarah Death. Oxford: Oxford University Press.

Lindgren, Astrid. (2009). The World's Best Karlson. Trans. Sarah Death. Oxford: Oxford University Press.

Lindgren, Astrid. (2010). Karlson Flies Again. Trans. Sarah Death. Oxford: Oxford University Press.

Lundqvist, Ulla. (1979). Århundradets Barn. Fenomenet Pippi Långstrump Och Dess Förutsättningar. Stockholm: Rabén \& Sjögren.

Lundqvist, Ulla. (1989). The Child of the Century. The Lion and the Unicorn, 13(2), 97-102.

Nietzsche, Friedrich (2004). Beyond Good and Evil. Trans. Helen Zimmern. Accessed November 07, 2019 from https://epdf.pub/beyond-good-and-evil96ec9745686ab79b12910933fa7817ef8468.html.

Nikolajeva, Maria. (2007). Astrid Lindgren - Famous and Unknown. Barnboken, 30(1-2), 1-5.

Nikolajeva, Maria. (2011). Visualizing People: Multimodal Character Construction in Astrid Lindgren's Works. In Bettina Kümmerling-Meibauer and Astrid Surmatz (Eds.), Beyond Pippi Longstocking: Intermedial and International Approaches to Astrid Lindgren's Work (pp. 125-136). London: Routledge.

Nodelman, Perry, and Reimer, Mavis. (2003). The Pleasures of Children's Literature. Boston, MA: Allyn and Bacon.

Scott, Carole. (2007). Harnessing the Monstrous: the Dark Side of Astrid Lindgren. Barnboken, 30(1-2), 75-82.

Strömstedt, Margareta. (2015). Astrid Lindren. Opowieść o życiu i twórczości. Trans. Anna Węglińska. Warszawa: Wydawnictwo Marginesy.

Tigges, Wim. (1988). An Anatomy of Literary Nonsense. Amsterdam: Rodopi.

Tulloch, Bonnie. (2015). A Spoonful of Silly: Examining the Relationship between Children's Nonsense Verse and Critical Literacy. M.A. Thesis, University of British Columbia.

von Zweigbergk, Eva. (1965). Barnboken i Sverige 1750-1950. Stockholm: Rabén \& Sjögren.

Winch, Peter. (1958). The Idea of a Social Science and Its Relation to Philosophy. London: Routledge.

Wittgenstein, Ludwig. (1986). Philosophical Investigations. Oxford: Basil Blackwell.

Publisher's Note Springer Nature remains neutral with regard to jurisdictional claims in published maps and institutional affiliations. 